INSTITUTE OF FORESTRY • BELGRADE

INSTITUT ZA ŠUMARSTVO • BEOGRAD

SUSTAINABLE FORESTRY

COLLECTION 79-80, 2019
ODRŽIVO ŠUMARSTVO

ZBORNIK RADOVA 79-80, 2019

UDK 630*180:551.581(497.11 Belgrade)

Original scientific paper

\title{
THE REGIONAL CLIMATE MODEL (REG-IN) FOR FORECASTING THE ADAPTIVITY OF FOREST ECOSYSTEMS IN BELGRADE
}

\author{
Tatjana RATKNIĆl, Mihailo RATKNIĆ ${ }^{1}$, Lazar VUKADINOVIĆ ${ }^{2}$
}

\begin{abstract}
Regional climate modelling with regional climate models has become a part of modern research with a wide range of applications. This article examines the latest segments in the study of regional climate modeling used to assess the adaptivity and survival of particular forest species in changing conditions. It presents the results of the regional climate model (acronym REG-IN) used to predict the adaptive capacity of forest ecosystems in Belgrade. Compared to the SXG and E-P models, the REG-IN model exhibits certain deviations due to the specific environmental conditions of the area. These data have made it possible to predict the future rate of survival of individual forest ecosystems.
\end{abstract}

Keywords: regional model, forest ecosystems, adaptation, survival, REG-IN

\section{REGIONALNI KLIMATSKI MODEL (REG-IN) U FUNKCIJI PREDVIDJANJA ADAPTIVNIH MOGUĆNOSTI ŠUMSKIH EKOSISTEMA NA PODRUČJU BEOGRADA}

Izvod: Regionalno modeliranje klime sa regionalnim klimatskim modelima postao je deo savremenog istraživanja i omogućava upotrebu u širokom spektru primene. U ovom radu preispituju se najnoviji segmenti u istraživanju regionalnog klimatskog modelovanja u funkciji adaptacije i opstanka pojedinih šumskih vrsta u novonastalim uslovima. Prikazani su rezultati regionalnog klimatskog modela (akronim REG-IN) u funkciji predvidjanja adaptivnih mogućnosti šumskih ekosistema na području Beograda. U poredjenju sa modelima SXG i E-P, model REG-IN pokazuje izvesna odstupanja koja su uslovljena specifičnim ekološkim uslovima područja. Ovi podaci su omogućili da se predviti stepen opstanka pojedinih šumskih ekosistema u budućnosti.

\footnotetext{
${ }^{1}$ Institute of Forestry, Kneza Viseslava 3, 11030 Republic of Serbia

${ }^{2}$ Weston Solutions inc., 205 Campus drive, Edison NJ 08837, USA
} 
Ključne reči: regionalni model, šumski ekosistemi, adaptacija, opstanak, REG-IN

\section{INTRODUCTION}

Climate change significantly contributes to the introduction of new approaches in forestry. These approaches emerge from the study of the effects of global and regional climatic changes (studies of different climate scenarios, changes in the concentration of greenhouse gases, ozone layer state, changes in the intensity of ultraviolet radiation, etc.).

The results of these studies should serve to determine:

- the response of forest ecosystems to climate change;

- the impact of climate change on biodiversity;

- the degree of impact and response of species to climate change;

- the importance of global climate change and the possibility of new species and subspecies to emerge under changing climate conditions;

- the occurrence of weed and invasive species, insects, plant diseases, etc.

Human activity has destroyed a large number of habitats. These habitats have often been fragmented or damaged by long-term pollution from various sources.

Global climate models can form a good basis for climate projections. However, their spatial resolution is so low that they cannot provide an accurate simulation of climate in the areas with pronounced and complex orographic features. In these circumstances, downscaling must be used. Downscaling refers to any method used to create higher-resolution simulations from the data obtained from global climate models (Giorgi \& Mearns 1999).

Some of these methods are "dynamical", which means that they use regional climate models to simulate future climate.

Other methods of downscaling are "statistical". They allow for the production of high-resolution projections. Statistical models are computationally cheap and quick to run, but they don't necessarily represent the physical dynamics of the local climate (Reich KD et al., 2018).

Representing the local physical dynamics is important because it can have a major impact on the local changes caused by global warming.

\section{MATERIAL AND METHODS}

Mean, minimum, and maximum temperature and precipitation data for the period 1871 to 2018 were used to construct the climate models. This article will present the data of the climate model for air temperatures.

The reference period (1871 - 1900) was taken as a parameter for assessing the survival of forest ecosystems. Potential and actual vegetation of the Belgrade area today was formed by climate conditions that prevailed in this period.

We developed a statistical model that mimics a dynamic model. 
The resulting climate models were compared with the SINTEX-G (SXG) Global Model and the EBU-POP Regional Model presented in "Change in climate indices for Serbia to the SRES-A1B and SRES-A2 scenarios" (Krzić et al., 2011). SX-G is a global atmospheric-ocean general circulation model developed at CMCC/ INGV (Centro Euro-Mediterraneo per and Cambiamenti Climatici/Istituto Nazionale di Geofisica e Vulcanologia) in Bologna, Italy (Gualdi et al., 2003a, 2003b; Guilyardi et al 2003).

Model results (REG-IN) are shown for A1B and A2 scenarios. Regarding the concentration of greenhouse gases, the A1B scenario can be characterized as "moderate" and the A2 scenario as "high". At the end of the twenty-first century, one of the greenhouse gases $\mathrm{CO} 2$ will reach the values around $690 \mathrm{ppm}$ according to the A1B scenario and around $850 \mathrm{ppm}$ according to the A2 scenario. This is 2 to 2.2 times the current value of $385 \mathrm{ppm}$.

The article presents data for the following three future periods: 2021-2050, 2051-2080, and 2081-2100.

To monitor climate change through existing models, the data for the reference period of 1961-1990 is also provided. This is the period most researchers take as a reference period when comparing their models.

The results are presented in tables and graphs.

\section{RESEARCH RESULTS}

Projections of the EURO-CORDEX initiative suggest that European land areas will warm faster on average than global land areas, in the range of 1 $4.5^{\circ} \mathrm{C}$ under the RCP4.5 scenario, and in the range of $2.5-5.5^{\circ} \mathrm{C}$ under the RCP8.5 by the end of the century (Jacob et al., 2014), while the number of heatwaves will be increasing in the same period (projected to occur as often as every two years in the second half of the 21st century) under the RCP8.5 scenario (EEA, 2016a). With the increase in mean annual temperature, rainfall is projected to increase by up to $25 \%$ in central and northern Europe, while a significant decrease is expected in southern Europe. By the end of the century, extreme daily rainfall will decrease by up to $25 \%$ in some parts of southern Europe, while it will increase by the same value in central and eastern Europe (Jacob et al., 2014).

The existing climate change projections for Serbia predict a trend of increasing temperatures for the $\mathrm{A} 1 \mathrm{~B}$ and $\mathrm{A} 2$ scenarios for the three study periods (2011-2040, 2041-2070, and 2071-2100) (MEP, 2015). The following temperature changes are expected for the study periods:

1. 2011-2040 - a temperature increase of $0.5-0.9^{\circ} \mathrm{C}$ for the A1B and 0.3$0.7^{\circ} \mathrm{C}$ for the $\mathrm{A} 2$ scenario;

2. 2041-2070 - a temperature increase of $1.8-2.2^{\circ} \mathrm{C}$ for the A1B and 1.6$2.0^{\circ} \mathrm{C}$ for the $\mathrm{A} 2$ scenario;

3. 2071-2100 - a temperature increase of $3.6-4.0^{\circ} \mathrm{C}$ for the $\mathrm{A} 1 \mathrm{~B}$ and 3.2$3.6^{\circ} \mathrm{C}$ for the $\mathrm{A} 2$ scenario.

The most pronounced warming, which exceeds $4.0^{\circ} \mathrm{C}$ by the end of the century, is expected for the summer and autumn seasons (MEP, 2015). 
Summer warming in the Balkans and western Turkey will be $5-6^{\circ} \mathrm{C}$ for 2071-2100 according to the A2 scenario (Gao \& Giorgi (2008). ICTP-RegCM3 for 2071-2100 and the A2 scenario project an increase of $7^{\circ} \mathrm{C}$ in the Balkan countries including Serbia (Önol \& Semazzi (2009).

Table 1 provides mean air temperatures by month for the reference periods (1871-1900 and 1961-1990) and the model values obtained for the three projected periods (2021-2050; 2051-2080; 2081-2100). These values are also shown in Graph 1.

Table 1 shows the mean air temperature values for all the study periods. Table 2 provides a comparison of the seasonal mean air temperature by study period with the global and regional models. The following four seasons are distinguished:

1. December, January, February (DJF),

2. March, April, May (MAM),

3. June, July, August (JJA) and

4. September, October, November (SON).

Table 1. Mean air temperature by study period

\begin{tabular}{|c|c|c|c|c|c|c|c|c|c|c|c|c|c|}
\hline \multirow{2}{*}{ Periods } & \multicolumn{12}{|c|}{ Months } & \\
\hline & $\mathrm{J}$ & $\mathrm{F}$ & $\mathrm{M}$ & $\mathrm{A}$ & $\mathrm{M}$ & $\mathrm{J}$ & $\mathrm{J}$ & $\mathrm{A}$ & $\mathrm{S}$ & $\mathrm{O}$ & $\mathrm{N}$ & $\mathrm{D}$ & Ann. \\
\hline $1871-1900$ & -1.1 & 0.7 & 6.1 & 11.8 & 16.1 & 19.7 & 22.2 & 21.2 & 17.3 & 12.4 & 5.8 & 0.8 & 11.1 \\
\hline 1961-1990 & 0.3 & 2.6 & 7.0 & 12.4 & 17.1 & 20.1 & 21.7 & 21.3 & 17.7 & 12.5 & 7.0 & 2.5 & 11.9 \\
\hline $2021-2050$ & 4.0 & 6.3 & 9.6 & 14.6 & 20.0 & 23.0 & 24.0 & 24.6 & 19.0 & 13.1 & 9.7 & 4.6 & 14.4 \\
\hline $2051-2080$ & 4.6 & 7.0 & 10.1 & 15.0 & 20.6 & 23.4 & 24.2 & 25.1 & 19.2 & 13.2 & 10.2 & 5.0 & 14.8 \\
\hline $2081-2100$ & 5.2 & 7.8 & 10.5 & 15.4 & 21.1 & 23.9 & 24.5 & 25.6 & 19.5 & 13.3 & 10.7 & 5.4 & 15.2 \\
\hline
\end{tabular}

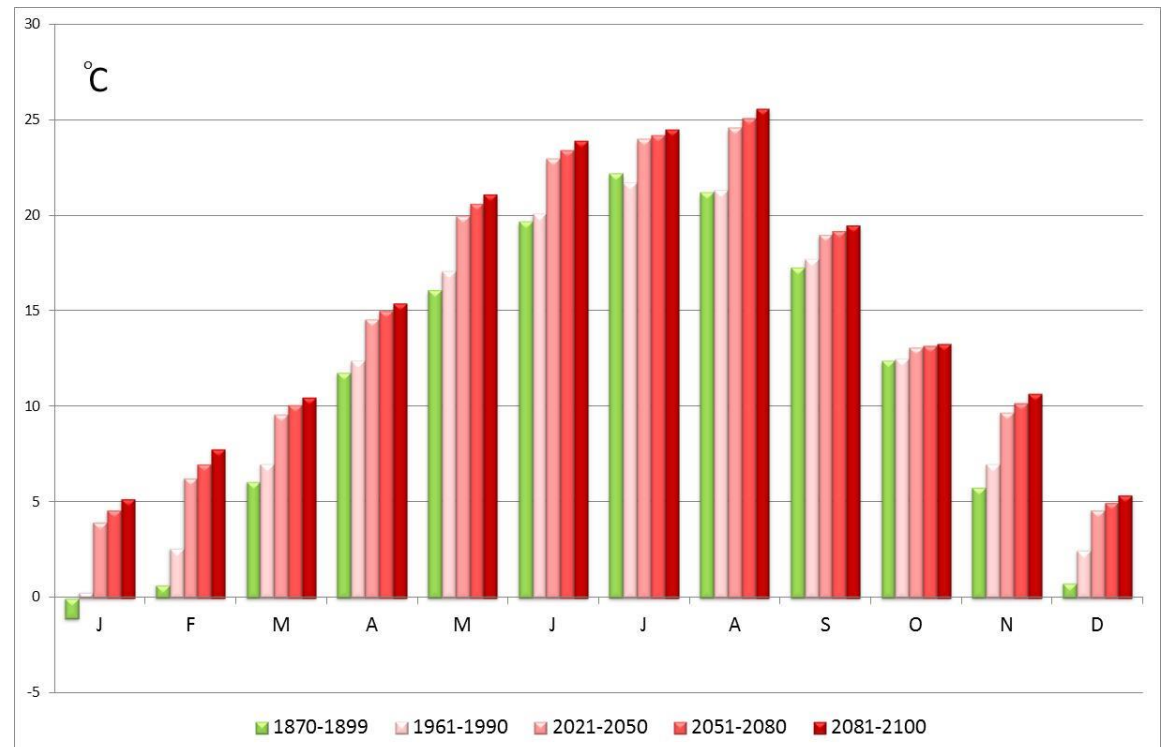

Graph 1. Mean air temperature by month, reference period, and projected period 
Table 2. Seasonal air temperatures by study period with the global and regional models

\begin{tabular}{|c|c|c|c|c|c|c|c|c|c|}
\hline \multirow{3}{*}{ Seasons } & \multicolumn{9}{|c|}{ Periods } \\
\hline & \multirow{2}{*}{$\begin{array}{c}1871- \\
1900 \\
\text { RP }\end{array}$} & \multirow{2}{*}{$\begin{array}{c}\text { 1961- } \\
1990 \\
\text { RF-2 }\end{array}$} & $\begin{array}{l}2021- \\
2050\end{array}$ & $\begin{array}{l}2051- \\
2080\end{array}$ & $\begin{array}{l}2081- \\
2100\end{array}$ & \multirow{2}{*}{$\begin{array}{c}2071- \\
2100 \\
\text { A1B } \\
(\mathrm{E}-\mathrm{P})\end{array}$} & \multirow{2}{*}{$\begin{array}{c}2071- \\
2100 \\
\text { A1B }\end{array}$} & \multirow{2}{*}{$\begin{array}{c}2071- \\
2100 \\
\text { A2 } \\
(\mathrm{E}-\mathrm{P})\end{array}$} & \multirow{2}{*}{$\begin{array}{c}2071- \\
2100 \\
\mathrm{~A} 2 \\
(\mathrm{SXG})\end{array}$} \\
\hline & & & \multicolumn{3}{|c|}{ REG-IN model } & & & & \\
\hline Designation & $\mathrm{a}$ & $\mathrm{b}$ & $\mathrm{c}$ & $\mathrm{d}$ & $\mathrm{e}$ & $\mathrm{f}$ & $\mathrm{g}$ & $\mathrm{h}$ & $\mathrm{i}$ \\
\hline MAM & 11.3 & 12.1 & 14.2 & 15.5 & 17.1 & 15.4 & 13.7 & 16.6 & 14.2 \\
\hline JJA & 21.0 & 21.0 & 24.1 & 25.9 & 28.0 & 26.9 & 28.9 & 30.9 & 29.7 \\
\hline SON & 11.8 & 12.4 & 13.3 & 13.7 & 14.1 & 14.5 & 16.0 & 15.2 & 16.8 \\
\hline DJF & 0.1 & 1.8 & 3.4 & 4.1 & 4.9 & 4.7 & 4.8 & 5.6 & 5.6 \\
\hline
\end{tabular}

Legend: RF - reference period a-1871-1900; RF-2 Reference period 2 b-1961-1990; Reg-IN model c-2021-2050; d-2051-2080; e-2081-2100; (A1B E-P) f-2071-2100; (A1B SXG) g-2071-2100; (A2 E-P) h-2071-2100; (A2 SXG) i- 2071-2100;

Compared to the reference period, changes in mean air temperature for the December-January-February (DJF) season range from +3.30C (2021-2050) to +4.00C (2081-2100) according to the REG-IN model. Compared to the E-P and SXG models, mean air temperatures have approximately the same values and differ by 0.1 to $0.2^{\circ} \mathrm{C}$ compared to the $\mathrm{A} 1 \mathrm{~B}$ scenario, while compared to the $\mathrm{A} 2$ scenario the values are lower by $0.7^{\circ} \mathrm{C}$ (Table 2 , Graph 2).
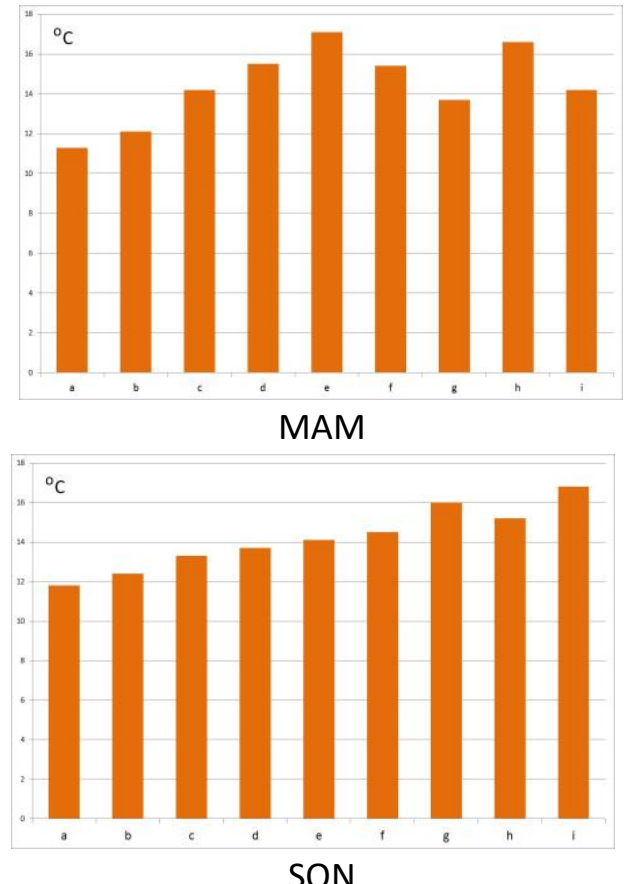

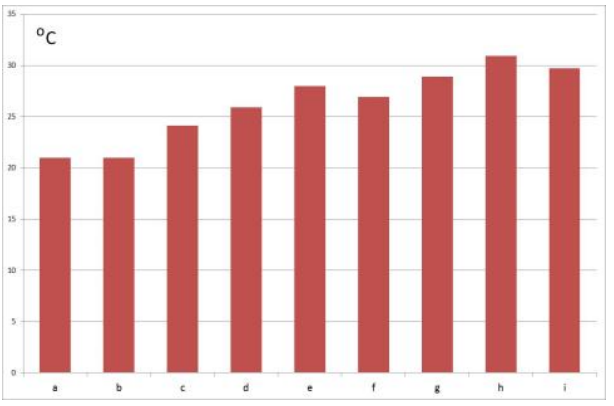

JJA

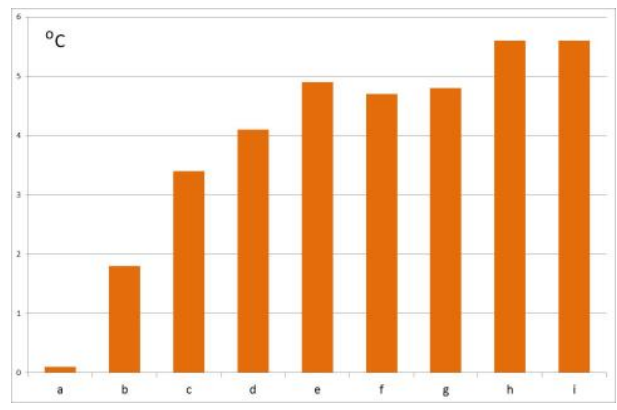

DJF

Graph 2. Seasonal air temperatures by study period with the global and regional models

According to the REG-IN model, the mean air temperatures for the MarchApril-May (MAM) season range from $+3.1^{\circ} \mathrm{C}(2021-2050)$ to $+5.8^{\circ} \mathrm{C}(2081-2100)$ 
compared to the reference period. Compared to the A1B scenario, the REG-IN model temperature data are higher by $1.7^{\circ} \mathrm{C}(\mathrm{E}-\mathrm{P})$ and $3.4^{\circ} \mathrm{C}(\mathrm{SXG})$ respectively. Compared to the $\mathrm{A} 2$ scenario, the values are higher by $1.1^{\circ} \mathrm{C}(\mathrm{E}-\mathrm{P})$ and $+2.9^{\circ} \mathrm{C}$ (SXG) respectively (Table 2, Graph 2).

Regarding the June-July-August (JJA) season in the REG-IN model, the deviation of the mean air temperature from the reference period ranges from $+3.1^{\circ} \mathrm{C}(2021-2050)$ to $+7.0^{\circ} \mathrm{C}$ (2081-2100). Compared to the A1B scenario, the REG-IN model temperature data are higher by $1.1^{\circ} \mathrm{C}(\mathrm{E}-\mathrm{P})$ and lower by $0.9^{\circ} \mathrm{C}$ (SXG). Compared to the $\mathrm{A} 2$ scenario, the values are lower by $1.9^{\circ} \mathrm{C}(\mathrm{E}-\mathrm{P})$ and $1.7^{\circ} \mathrm{C}(\mathrm{SXG})$, respectively (Table 2, Graph 2).

For the September-October-November (SON) season, according to the REG-IN model, the deviation of the mean air temperature from the reference period ranges from $+1.9^{\circ} \mathrm{C}(2021-2050)$ to $+2.3^{\circ} \mathrm{C}$ (2081-2100). Compared to the A1B scenario, the REG-IN model temperature data are lower by $0.4^{\circ} \mathrm{C}(\mathrm{E}-\mathrm{P})$ and $1.9^{\circ} \mathrm{C}(\mathrm{SXG})$ respectively. Compared to the $\mathrm{A} 2$ scenario, the values are lower by $1.1^{\circ} \mathrm{C}(\mathrm{E}-\mathrm{P})$ and $2.7^{\circ} \mathrm{C}(\mathrm{SXG})$, respectively (Table 2, Graph 2).

Table 3. Mean maximum air temperature by study period

\begin{tabular}{|c|c|c|c|c|c|c|c|c|c|c|c|c|c|}
\hline \multirow{2}{*}{ Periods } & \multicolumn{12}{|c|}{ Months } & \\
\hline & $\mathrm{J}$ & $\mathrm{F}$ & $\mathrm{M}$ & A & $M$ & $J$ & $J$ & A & $\mathrm{S}$ & $\mathrm{O}$ & $\mathrm{N}$ & D & Ann. \\
\hline $1871-1900$ & 2.1 & 5.2 & 11.2 & 17.0 & 21.6 & 25.0 & 27.9 & 27.4 & 23.3 & 17.5 & 9.7 & 4.1 & 16.0 \\
\hline $1961-1990$ & 3.4 & 6.2 & 11.7 & 17.5 & 22.4 & 25.3 & 27.2 & 27.2 & 23.7 & 18.1 & 11.0 & 5.5 & 16.6 \\
\hline $2021-2050$ & 6.1 & 9.5 & 14.0 & 19.3 & 24.1 & 27.6 & 29.7 & 30.1 & 24.3 & 19.1 & 12.8 & 6.3 & 18.4 \\
\hline $2051-2080$ & 7.5 & 11.7 & 15.5 & 20.3 & 24.8 & 28.5 & 30.9 & 31.4 & 24.4 & 19.8 & 13.7 & 6.7 & 19.2 \\
\hline $2081-2100$ & 9.1 & 14.4 & 17.3 & 21.5 & 25.5 & 29.7 & 32.3 & 33.1 & 24.5 & 20.7 & 14.7 & 7.0 & 20.2 \\
\hline
\end{tabular}

Table 4. Comparison of the mean maximum air temperature by study period with regional models

\begin{tabular}{|c|c|c|c|c|c|c|c|}
\hline \multirow{3}{*}{ Seasons } & \multicolumn{7}{|c|}{ Periods } \\
\hline & $1871-1900$ & $1961-1990$ & $2021-2050$ & $2051-2080$ & $2081-2100$ & $2071-2100$ & $2071-2100$ \\
\hline & $\mathrm{RP}$ & RF-2 & & REG-IN mode & & A1B & A2 \\
\hline MAM & 16.6 & 17.2 & 19.1 & 20.0 & 21.2 & 19.5 & 20.8 \\
\hline JJA & 26.7 & 26.6 & 29.1 & 30.2 & 31.5 & 35.3 & 36.7 \\
\hline SON & 16.8 & 17.6 & 18.3 & 18.5 & 18.6 & 19.1 & 19.8 \\
\hline DJF & 3.8 & 5.1 & 7.0 & 8.1 & 9.3 & 7.3 & 7.9 \\
\hline
\end{tabular}

Changes in the mean maximum air temperature for the December-JanuaryFebruary (DJF) season, according to the REG-IN model, deviate from to the reference period by $+3.2^{\circ} \mathrm{C}(2021-2050)$ and $+4.3^{\circ} \mathrm{C}(2081-2100)$. Compared to the E-P Model and the A1B scenario, the mean maximum air temperature values are higher by $2.2^{\circ} \mathrm{C}$, and $1.2^{\circ} \mathrm{C}$ compared to the $\mathrm{A} 2$ scenario (Table 4).

According to REG-IN model for the March-April-May (MAM) season, the mean maximum air temperatures are $+2.5^{\circ} \mathrm{C}(2021-2050)$, and $+3.4^{\circ} \mathrm{C}(2051-2080)$ to $+4.6^{\circ} \mathrm{C}(2081-2100)$ compared to the reference period. Compared to the A1B scenario, the REG-IN model temperature values are higher by $1.7^{\circ} \mathrm{C}(\mathrm{E}-\mathrm{P})$ and compared to the A2 scenario, they are higher by $0.4^{\circ} \mathrm{C}(\mathrm{E}-\mathrm{P})$. (Table 4$)$.

According to the REG-IN model for the June-July-August (JJA) season, the mean maximum air temperatures are $+2.4^{\circ} \mathrm{C}(2021-2050),+3.5^{\circ} \mathrm{C}(2051-2080)$ 
and $+4.8^{\circ} \mathrm{C}$ (2081-2100) compared to the reference period. Compared to the A1B scenario, the REG-IN model temperature values are lower by $3.8^{\circ} \mathrm{C}(\mathrm{E}-\mathrm{P})$ and compared to the $\mathrm{A} 2$ scenario by $5.2^{\circ} \mathrm{C}$ (E-P), (Tabela 4).

According to the REG-IN Model for the September-October-November (SON) season, the mean maximum air temperatures are $+2.5^{\circ} \mathrm{C}(2021-2050)$ and $+2.7^{\circ} \mathrm{C}(2051-2080)$ to $+2.8^{\circ} \mathrm{C}$ (2081-2100) compared to the reference period. Compared to the A1B scenario, the REG-IN Model temperature values are lower by $0.5^{\circ} \mathrm{C}(\mathrm{E}-\mathrm{P})$ and $1.2^{\circ} \mathrm{C}(\mathrm{E}-\mathrm{P})$ compared to the $\mathrm{A} 2$ scenario. (Table 4$)$.

Table 5. Mean minimum air temperature by study period

\begin{tabular}{|c|c|c|c|c|c|c|c|c|c|c|c|c|c|}
\hline \multirow[b]{2}{*}{ Periods } & \multicolumn{12}{|c|}{ Months } & \multirow[b]{2}{*}{ Ann } \\
\hline & $\mathrm{J}$ & $\mathrm{F}$ & $M$ & A & $\mathrm{M}$ & $\mathrm{J}$ & $\mathrm{J}$ & A & $\mathrm{S}$ & $\mathrm{O}$ & $\mathrm{N}$ & $\mathrm{D}$ & \\
\hline $\begin{array}{l}1871- \\
1900\end{array}$ & -2.3 & -5.3 & -3.0 & 1.7 & 6.7 & 10.8 & 14.3 & 16.1 & 15.3 & 12.1 & 7.9 & 2.0 & 6.4 \\
\hline $\begin{array}{l}1961- \\
1990\end{array}$ & -2.3 & -0.3 & 3.2 & 7.8 & 12.1 & 15.0 & 16.3 & 16.1 & 13.0 & 8.4 & 4.0 & -0.1 & 7.8 \\
\hline $\begin{array}{l}2021- \\
2050\end{array}$ & -0.8 & 1.9 & 6.1 & 10.5 & 14.8 & 17.8 & 18.7 & 18.1 & 13.3 & 8.3 & 3.7 & -0.1 & 9.4 \\
\hline $\begin{array}{l}2051- \\
2080\end{array}$ & -0.6 & 3.1 & 8.1 & 12.4 & 16.7 & 19.3 & 19.8 & 18.6 & 12.8 & 7.3 & 2.7 & -0.8 & 10.0 \\
\hline $\begin{array}{l}2081- \\
2100\end{array}$ & -0.5 & 4.3 & 10.1 & 14.4 & 18.6 & 20.9 & 20.8 & 19.0 & 12.3 & 6.4 & 1.8 & -1.4 & 10.6 \\
\hline
\end{tabular}

Table 6. Mean minimum and mean maximum air temperatures

\begin{tabular}{|l|c|c|c|c|c|c|c|c|}
\hline \multirow{2}{*}{ Periods } & \multicolumn{3}{|c|}{ Mean minimum air temperature } & \multicolumn{4}{c|}{ Mean maximum air temperature } \\
\cline { 2 - 9 } & MAM & JJA & SON & DJF & MAM & JJA & SON & DJF \\
\hline $1871-1900$ & 6.4 & 15.2 & 7.3 & -3.5 & 16.6 & 26.7 & 16.8 & 3.8 \\
\hline $1961-1990$ & 7.7 & 15.8 & 8.5 & -0.9 & 17.2 & 26.6 & 17.6 & 5.1 \\
\hline $2021-2050$ & 9.8 & 19.1 & 9.9 & 0.8 & 19.1 & 29.1 & 18.3 & 7.0 \\
\hline $2051-2080$ & 11.1 & 21.0 & 10.6 & 1.5 & 20.0 & 30.2 & 18.5 & 8.1 \\
\hline $2081-2100$ & 12.6 & 23.3 & 11.3 & 2.1 & 21.2 & 31.5 & 18.6 & 9.3 \\
\hline
\end{tabular}

Changes in the mean minimum air temperature for the December-JanuaryFebruary (DJF) season, according to the REG-IN model, are $+4.3^{\circ} \mathrm{C}$ (2021-2050), $+5.0^{\circ} \mathrm{C}(2051-2080)$ and $+5.6^{\circ} \mathrm{C}(2081-2100)$ compared to the reference period. Compared to the E-P Model and the A1B scenario, the mean minimum air temperatures are lower by $0.5^{\circ} \mathrm{C}$ and by $1.6^{\circ} \mathrm{C}$ compared to the $\mathrm{A} 2$ Scenario (Table 7).

Table 7. Comparison of the mean minimum air temperature by study period with regional models

\begin{tabular}{|c|c|c|c|c|c|c|c|}
\hline \multirow{3}{*}{ Seasons } & \multicolumn{7}{|c|}{ Periods } \\
\hline & $\begin{array}{c}1871- \\
1900\end{array}$ & $\begin{array}{c}1961- \\
1900\end{array}$ & $\begin{array}{l}2021- \\
2050\end{array}$ & $\begin{array}{l}2051- \\
2080\end{array}$ & $\begin{array}{l}2081- \\
2100\end{array}$ & $\begin{array}{l}2071- \\
2100\end{array}$ & $\begin{array}{l}2071- \\
2100\end{array}$ \\
\hline & RP & RF-2 & & EG-IN mode & & A1B & A2 \\
\hline MAM & 6.4 & 7.7 & 9.8 & 11.1 & 12.6 & 12.3 & 13.4 \\
\hline JJA & 15.2 & 15.8 & 19.1 & 21.0 & 23.3 & 25.4 & 26.6 \\
\hline SON & 7.3 & 8.5 & 9.9 & 10.6 & 11.3 & 11.9 & 11.9 \\
\hline DJF & -3.5 & -0.9 & 0.8 & 1.5 & 2.1 & 2.6 & 3.7 \\
\hline
\end{tabular}



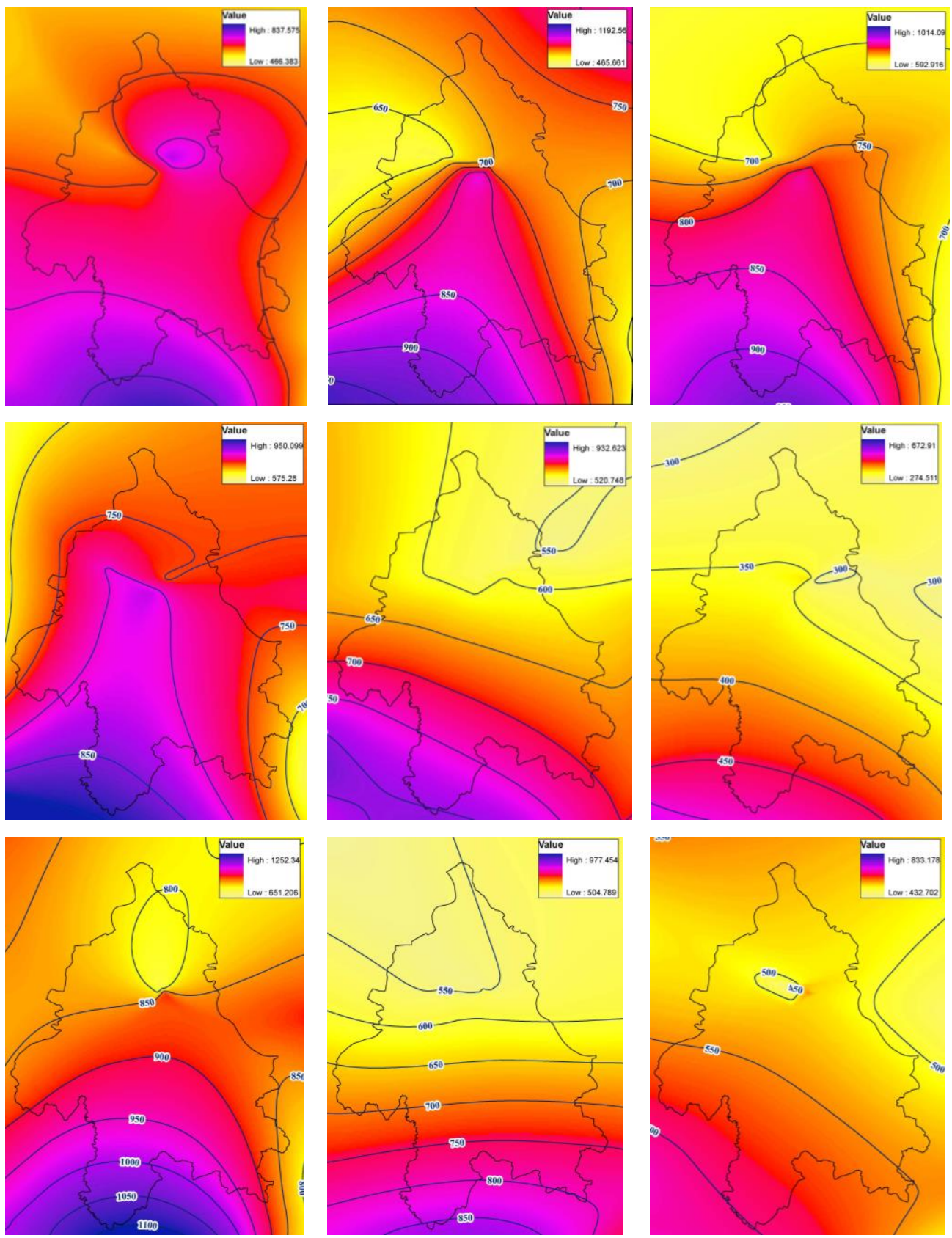

Picture 1. Simulation of the REG-IN Model 
According to the REG-IN model for the March-April-May (MAM) season, the mean minimum air temperature range from $+3.4^{\circ} \mathrm{C}(2021-2050)$ and $+4.7^{\circ} \mathrm{C}$ (2051-2080) to $+6.2^{\circ} \mathrm{C}$ (2081-2100) compared to the reference period. The temeperature values obtained in the REG-IN model are higher by $0.3^{\circ} \mathrm{C}$ than the values obtained in the A1B scenario (E-P) and lower by $0.8^{\circ} \mathrm{C}$ than the $\mathrm{A} 2$ scenario values (E-P) (Table 6).

According to the REG-IN model for the June-July-August (JJA) season, the mean minimum air temperature range from $+3.9^{\circ} \mathrm{C}(2021-2050)$ and $+5.8^{\circ} \mathrm{C}$ (2051-2080) to $+8.1^{\circ} \mathrm{C}$ (2081-2100) compared to the reference period. The temeperature values obtained in the REG-IN Model are lower by $2.1^{\circ} \mathrm{C}$ than in the A1B scenario (E-P) and $3.3^{\circ} \mathrm{C}$ compared to the A2 scenario (E-P), (Table 6).

According to the REG-IN Model for the September-October-November (SON) season, the mean minimum air temperature range from $+2.6^{\circ} \mathrm{C}(2021-2050)$ and $+3.3^{\circ} \mathrm{C}(2051-2080)$ to $+4.0^{\circ} \mathrm{C}(2081-2100)$ compared to the reference period. The temeperature values obtained in the REG-IN Model are lower by $0.6^{\circ} \mathrm{C}$ than in the A1B scenario (E-P) and by $0.6^{\circ} \mathrm{C}$ compared to the A2 scenario (E-P), (Table 6).

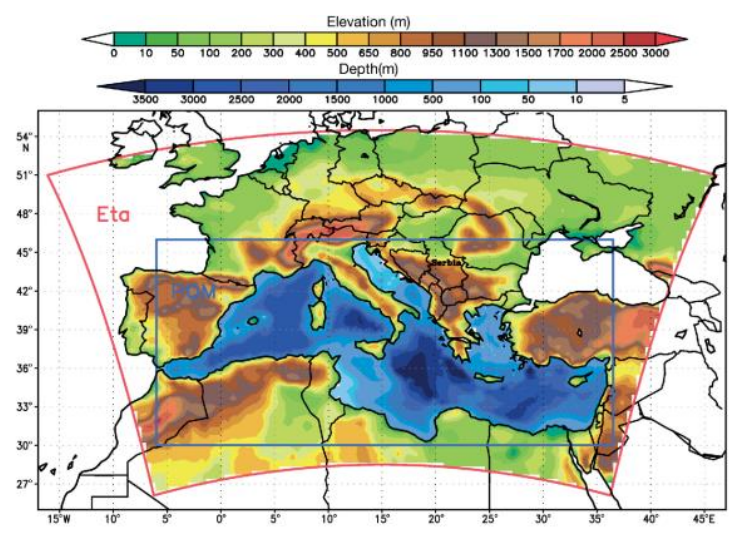

Picture 2. Model domains. Area bounded by outer line is the Eta Model domain; the inner rectangle represents the domain boundary of the Princeton Ocean Model (POM) (Krzić et al., 2011)

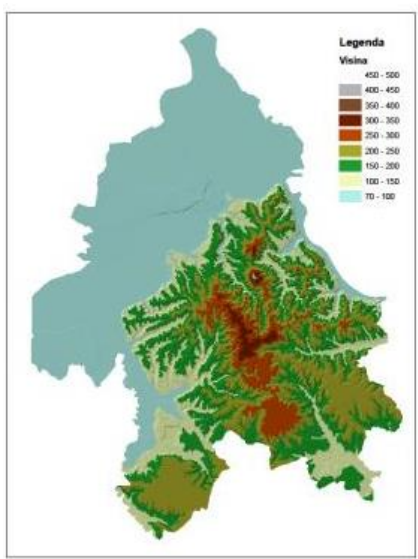

Picture 3. Area bounded by outer line is the REG-IN Model domain

\section{FORECASTS OF ADAPTIVE OPPORTUNITIES OF FOREST ECOSYSTEMS IN BELGRADE}

Based on the environmental characteristics of each site and the main species, the survival of all forest and shrub sites found in the Belgrade area was projected.

The model includes all the specific site features: location, size of the mountain massif, bedrock, climate, altitude, aspect, microclimate, potential forest community expansion (limited by orographic conditions), etc. This produced a realistic projection of environmental conditions. The term "habitat loss" refers to a 
drastic change in environmental habitat conditions in which a forest community exists today.

\section{G - FORESTS, FOREST HABITATS AND RELATED WOODLAND}

\section{AREAS}

\begin{tabular}{|c|c|c|c|c|}
\hline \multirow{2}{*}{\multicolumn{2}{|c|}{$\begin{array}{l}\text { G1 - BROADLEAVED DECIDUOUS FORESTS } \\
\text { G1.1 - Riverine forests of willow (Salix), alder (Alnus), and birch } \\
\text { (Betula) }\end{array}$}} & \multicolumn{3}{|c|}{ Period } \\
\hline & & $\begin{array}{l}2019- \\
2049\end{array}$ & $\begin{array}{l}2050- \\
2080\end{array}$ & $\begin{array}{l}2080- \\
2100\end{array}$ \\
\hline G1.1141 & $\begin{array}{l}\text { Continental willow (Salix) galleries on recent alluvial } \\
\text { deposits }\end{array}$ & $\mathrm{b}$ & A & A \\
\hline G1.1142 & Continental willow (Salix) galleries on gley soils & $\mathrm{b}$ & A & A \\
\hline G1.115 & Willow and poplar floodplain forests & A & A & A \\
\hline G1.116 & White poplar (Populus alba) floodplain forests & A & A & A \\
\hline G1.117 & $\begin{array}{l}\text { Black poplar (Populus } \\
\text { nigra) floodplain forests }\end{array}$ & A & A & A \\
\hline G1.119 & $\begin{array}{l}\text { Mixed floodplain forests of black poplar (Populus } \\
\text { nigra) white poplar (Populus alba) }\end{array}$ & A & A & A \\
\hline
\end{tabular}

G1.2 - Ash-alder (Fraxinus)-(Alnus) and oak (Quercus)-elm (Ulmus)-ash (Fraxinus) riverine forests

\begin{tabular}{|c|c|c|c|c|}
\hline G1.2231 & $\begin{array}{l}\text { Mixed forests of narrow-leafed ash (Fraxinus } \\
\text { angustifolia) and pedunculate oak (Quercus robus) } \\
\text { along large rivers }\end{array}$ & $\mathrm{a}, \mathrm{b}$ & $\mathrm{a}, \mathrm{b}$ & A \\
\hline G1.2233 & $\begin{array}{l}\text { Mixed forests of field ash (Fraxinus angustifolia), } \\
\text { pedunculate oak (Quercus robur) and } \\
\text { hornbeam (Carpinus betulus) along large rivers }\end{array}$ & $\mathrm{a}, \mathrm{b}$ & A & A \\
\hline G1.2234 & $\begin{array}{l}\text { Hygrophilic forests of pedunculate oak (Quercus } \\
\text { robur) and common hornbeam (Carpinus betulus) }\end{array}$ & $a, b$ & A & A \\
\hline \multicolumn{5}{|c|}{ G1.4 - Broadleaved swamp forests that don`t grow on acid peat } \\
\hline G1.42 & Oak (Quercus) swamp forests & A & A & A \\
\hline G1.44 & $\begin{array}{l}\text { Narrow-leafed ash (Fraxinus } \\
\text { angustifolia) swamp forests }\end{array}$ & A & A & A \\
\hline \multicolumn{5}{|c|}{ G1.6 - Beech (Fagus) forests } \\
\hline G1.6911 & Moesian monodominant submontane beech forests & A & $\mathrm{A}$ & $\mathrm{A}$ \\
\hline G1.6913 & $\begin{array}{l}\text { Moesian submontane beech forest with linden trees (Tilia } \\
\text { spp,) }\end{array}$ & A & A & A \\
\hline G1.6914 & $\begin{array}{l}\text { Moesian submontane beech forests with sessile oak trees } \\
\text { (Quercus petraea) }\end{array}$ & A & A & A \\
\hline \multicolumn{5}{|c|}{ G1.7 - Thermophilous deciduous forests } \\
\hline G1.7611 & Typical forests of Hungarian oak and Turkey oak & $\mathrm{h}$ & $\mathrm{h}$ & $\mathrm{h}$ \\
\hline G1.7612 & $\begin{array}{l}\text { Forests of Hungarian oak and Turkey oak with butcher`s } \\
\text { broom (Ruscus aculeatus) }\end{array}$ & $\mathrm{h}$ & $\mathrm{h}$ & $\mathrm{h}$ \\
\hline G1.763 & Moesian Oak of Virgil (Quercus virgiliana) forests & $\mathrm{f}, \mathrm{h}$ & $\mathrm{f}, \mathrm{h}$ & $\mathrm{f}, \mathrm{h}$ \\
\hline G1.7A12 & Pannonian Oak of Virgil (Quercus virgiliana) forests & $\mathrm{h}$ & $\mathrm{h}$ & $\mathrm{h}$ \\
\hline G1.7A14 & $\begin{array}{l}\text { Pannonian forests of pedunculate oak (Quercus } \\
\text { robur) on loess }\end{array}$ & $\mathrm{b}$ & $\mathrm{b}$ & $\mathrm{b}$ \\
\hline
\end{tabular}




\begin{tabular}{|l|l|c|c|c|}
\hline G1.7A15 & $\begin{array}{l}\text { Pannonian forests of sessile oak (Quercus } \\
\text { petraea) and Turkey oak (Quercus cerris) }\end{array}$ & A & A \\
\hline G1.8 - Acidophilous oak-dominated forests (Quercus) & A & A \\
\hline G1.871 & Moesian acidophilic sessile oak (Quercus petraea) forests & A & A \\
\hline $\begin{array}{l}\text { G1.A - Moeso-eutrophic forests of (Quercus), (Carpinus), (Fraxinus), (Acer), (Tilia), (Ulmus) and } \\
\text { related woodland }\end{array}$ & A & A & A \\
\hline G1.A1B1 & $\begin{array}{l}\text { Pannonian sessileoak-hornbeam (Quercus petraea) - } \\
\text { (Carpinus betulus) forests }\end{array}$ & A & A & A \\
\hline G1.A1C1 & $\begin{array}{l}\text { Moesian sessileoak-hornbeam (Quercus petraea) - } \\
\text { (Carpinus betulus) forests }\end{array}$ & f,b & A & A \\
\hline G1.A24 & $\begin{array}{l}\text { Non-riverine ash (Fraxinus excelsior) forests with } \\
\text { linden trees (Tilia spp,) }\end{array}$
\end{tabular}

The table labels in the columns are: a - reduction of groundwater level; $b$ - reduction of the area of distribution; $h$ area expansion; f - occurs on a limestone bedrock; A - habitat loss

\section{CONCLUSIONS}

Climate models indicate that adaptive measures and climate change mitigation are necessary. It is still possible to avoid the worst-case scenarios provided that appropriate mitigation measures are applied. On the other hand, some climate changes are of such a character that we have to adapt to them. This means that reducing greenhouse gas emissions and adapting to climate change are not mutually exclusive but must be applied together (Reich et al., 2018).

The climate model-based analysis provides an opportunity to develop strategies to address the effects of climate change in the Belgrade area. Additional research is needed at this stage of model development to reduce errors of regional climate modeling (Giorgi et al, 2009). It is proposed to introduce an "ensemblebased approach" to modeling which provides information on climate change in the form of a probability density function.

The actual and potential vegetation in the Belgrade area will develop in conditions of increased temperature compared to the present circumstances. This trend of changes also indicates an increase in summer temperature extremes in the city area, which makes the conditions for the development of vegetation even more difficult.

Acknowledgment: This paper was realized within the project "Implementation of adaptive measures in the adaptation of forest ecosystems to climate change in the City of Belgrade" funded by the Secretariat for the Environment.

\section{REFERENCES}

EEA. (2016). Climate change, impacts, and vulnerability in Europe 2016 An indicatorbased report. EEA Report No 1/2017. https://doi.org/10.2800/66071

Gao, X., Giorgi, F. (2008): Increased aridity in the Mediterranean region under greenhouse gas forcing estimated from high-resolution simulations with a regional climate model. Global Planet Change 62: 195-209 
Giorgi, F., Mearns, LO. (1999): Introduction to special section: regional climate modeling revisited. J Geophys Res 104: 6335-6352

Gualdi, S., Guilyardi, E., Navarra, A., Masina, S. (2003b): The interannual variability in the tropical Indian Ocean as simulated by a CGCM. Clim Dyn 20: 567-582

Gualdi, S., Navarra, A., Guilyardi, E., Delecluse, P. (2003a): Assessment of the tropical Indo-Pacific climate in the SINTEX CGCM. Ann Geophys 46: 1-26

Guilyardi, E., Delecluse, P., Gualdi, S., Navarra, A. (2003): Mechanisms for ENSO phase change in a coupled GCM. J Clim 16: 1141-1158

IPCC Special Report on Emission Scenarios, SRES;

Jacob, D., Petersen, J., Eggert, B., Alias, A., Christensen, O. B., Bouwer, L. M., Yiou, P. (2014): EURO-CORDEX: new high-resolution climate change projections for European impact research. Regional Environmental Change, 14(2), 563-578.

Kržić, A., Tošić, I., Djurdjević, V., Veljković, K., Rajković, B. (2011): Changes in climate indices for Serbia according to the SRES-A1B and SRES-A2 scenarios, Climate Research, Vol. 49: 73-86, doi: 10.3354/cr01008

MPZŽS - Ministarstvo poljoprivrede i zaštite životne sredine. (2015). Prvi nacionalni plan adaptacije na izmenjene klimatske uslove za Republiku Srbiju Nacrt. Beograd.

Nakicenovic and Swart, 2000 (http://www-pcmdi.llnl.gov/ipcc/about_ipcc.php)

Önol, B., Semazzi, F. (2009): Regionalization of climate change simulations over the eastern Mediterranean. J Clim 22: 1944-1961

Petar, D., Vranić, P. (2018): Razvoj modela za integrisano upravljanje izborom mera prilagođavanja na klimatske promene na lokalnom nivou, Doktorska disertacija , Univerzitet u Nišu, Fakultet zaštite na radu u Nišu

Reich, KD., Berg, N., Walton, DB., Schwartz, M., Sun, F., Huang, X., Hall, A. (2018): Climate Change in the Sierra Nevada: California's Water Future, UCLA Center for Climate Science

\title{
THE REGIONAL CLIMATE MODEL (REG-IN) FOR FORECASTING THE ADAPTIVITY OF FOREST ECOSYSTEMS IN BELGRADE
}

\author{
Tatjana RATKNIĆ, Mihailo RATKNIĆ, Lazar VUKADINOVIĆ
}

\section{Summary}

Regional climate modelling with regional climate models has become a part of modern research with a wide range of applications. This article examines the latest segments in the study of regional climate modeling used to assess the adaptivity and survival of particular forest species in changing conditions. It presents the results of the regional climate model (acronym REG-IN) used to predict the adaptive capacity of forest ecosystems in Belgrade. Compared to the SXG and E-P models, the REG-IN model exhibits certain deviations due to the specific environmental conditions of the area. These data have made it possible to predict the future rate of survival of individual forest ecosystems. 


\title{
REGIONALNI KLIMATSKI MODEL (REG-IN) U FUNKCIJI PREDVIDJANJA ADAPTIVNIH MOGUĆNOSTI ŠUMSKIH EKOSISTEMA NA PODRUČJU BEOGRADA
}

\author{
Tatjana RATKNIĆ, Mihailo RATKNIĆ, Lazar VUKADINOVIĆ
}

\section{Rezime}

Regionalno modeliranje klime sa regionalnim klimatskim modelima postao je deo savremenog istraživanja i omogućava upotrebu u širokom spektru primene. U ovom radu preispituju se najnoviji segmenti u istraživanju regionalnog klimatskog modelovanja $\mathrm{u}$ funkciji adaptacije i opstanka pojedinih šumskih vrsta u novonastalim uslovima. Prikazani su rezultati regionalnog klimatskog modela (akronim REG-IN) u funkciji predvidjanja adaptivnih mogućnosti šumskih ekosistema na području Beograda. U poredjenju sa modelima SXG i E-P, model REG-IN pokazuje izvesna odstupanja koja su uslovljena specifičnim ekološkim uslovima područja. Ovi podaci su omogućili da se predviti stepen opstanka pojedinih šumskih ekosistema u budućnosti. 